UDC УДК 94(438)«15/17»:343.1

DOI: $10.24919 / 2519-058 x .11 .170698$

\title{
Ihor SMUTOK
}

PhD hab. (History), Associate Professor of Department of World History and Special Historical Disciplines, Drohobych Ivan Franko State Pedagogical University, 24 Ivan Franko Street, Drohobych, Ukraine, postal code 82100 (smutokigor@gmail.com)

ORCID: https://orcid.org/0000-0002-5430-163X

\section{Tetiana KOLOMOIETS}

PhD hab. (Law), Professor, Corresponding member of the National Academy of Legal Sciences of Ukraine, Honored Lawyer of Ukraine, Dean of Law Faculty of Zaporizhzhia National University, 66 Zhukovskoho Street, Zaporizhzhia, Ukraine, postal code69002 (t_deputy@ukr.net)

ORCID: https://orcid.org/ 0000-0003-1101-8073

ResearcherID: M-9082-2019 (http://www.researcherid.com/rid/ M-9082-2019)

\section{Ігор СМУТОК}

доктор історичних наук, доцент кафедри всесвітньої історії та спеціальних історичних дисииплін, Дрогобииький державний педагогічний університет ім. Івана Франка, вул. Івана Франка, 24, Дрогобич, Україна, індекс 82100 (smutokigor@gmail.com)

\section{Тетяна КОЛОМОЕЦь}

доктор юридичних наук, професор, член-кореспондент Начіональної академії правових наук Украӥни, заслужений діяч науки і техніки Украӥни, декан юридичного факультету Запорізького начіонального університету, вул. Жуковського, 66, м. Запоріжжя, Україна, індекс 69002 (t_deputy@ukr.net)

Бібліографічний опис статті: Smutok, I. \& Kolomoiets, T. (2019). The Judicial system in King board manors of Rus Voyevodstvo in the XVIth - XVIIIth centuries. Skhidnoievropeiskyi istorychnyi visnyk [East European Historical Bulletin], 11, 29-38. doi: 10.24919/2519-058x.11.170698

\section{THE JUDICIAL SYSTEM IN KING BOARD MANORS OF RUS VOYEVODSTVO IN THE XVIth - XVIIIth CENTURIES}

Summary. The purpose of the research - the reconstruction of the judicial system in king board manors of Rus province in the XVIth - XVIIIth centuries. The methodology of the research is based on the principles of historicism, objectivity. The following methods were used while carrying out the research: historical, problem-chronological, component-analysis. The scientific novelty of the work is determined by the fact that the reconstructed model of the judicial system within the limits of a separate administrative-territorial complex. It has been illustrated how the lower institutions functioned, which were intended to ensure the efficiency of legal proceedings in the everyday life of the population. It has been clarified how they interacted with judicial and administrative institutions located at one or more stages above. Conclusions. In the XVIth - XVIIIth centuries the judicial system in king board manors created a multilevel hierarchical model. Such kind of the multilevel hierarchical model was to a certain extent the reflection of the administrative apparatus since the government officials and the institutions 
were entrusted with the governing functions and were engaged in the legal proceedings. The civil courts, kraynyk courts, the collegiate courts formed the lower link of the judicial system in king board manors. They were the embodiment of the public administration relics, were based on the customary practice of the active involvement of the population in the legal field. The upper levels of the court system in king board manors consisted of the pidzhupnytskyi courts, the Vice-Administrative Courts and the Administrative Courts. They were organized by the administration as the castle courts (Sad grodzki) and the dominical courts in private estates.

Keys words: king board manors, Sambir economy, civil courts, collegial courts, castle authority, jurisdiction.

\section{СИСТЕМА СУДОЧИНСТВА У КОРОЛІВСЬКИХ СТОЛОВИХ МАЕТКАХ РУСБКОГО ВОСВОДСТВА У XVI - XVIII СТ.}

Анотація. Мета дослідження - реконструкиія сиситеми судочинства у королівських столових маєтках Руського воєводства у XVI - XVIII cm. Методологія дослідження базується на засадах, в основі яких - історизм, об' єктивність. Під час проведення дослідження використані такі методи як історичний, проблемно-хронологічний, компонент-аналізу. Наукова новизна визначається тим, що реконструqована модель системи правосуддя у межах окремого аміністративно-територіального комплексу. Показано, як функціонували низові інситуції, покликані забезпечити ефективність судочинства у повсякденному житті населення. 3 'ясовано, в який спосіб вони взаємодіяли з судово-адміністративними установами, розташованими на один або кілька щзаблів вище. Висновки Таким чином, судоустрій королівських столових маєтках у XVI - XVIII cm. творив багаторівневу ієрархічну модель. Вона була певною мірою віддзеркаленням адміністративного апарату, адже урядовиі та інституиії наділені управлінськими функиіями 3-поміж іншого займалися судочинством. Нижчі ланки формувалися з громадських, крайницьких, зборових судів. Вони уособлювали релікти громадського управління, грунтувалися на звичаєвій практиці з активним задіянням населення у правовій сфері. Верхні шаблі судоустрою складалися з піджупницьких, віщеадміністраторських, адміністраторських судів. Вони організовувалися адміністрачією на зразок гродських судів та домінікальних судів у приватних маєтках. Відсутність достатніх сил для контролю над повсякденною правовою практикою населення королівських столових маєтків та недосконалість правовї бази змушувала адміністрацію миритися з паралельним існуванням іншої відмінної системи права. Однак зі зміиненням апарату управління, підвищенням його ефективності, замкова влада у XVIII cm. позбулася залежності від громадсько-зборових судів. Як наслідок-громадсько-зборове судівнищтво занепадає. Громада і збори втрачають свої правові функиї̈, крайники перестають бути частиною громадського самоврядування й перетворюються на замкових урядовиів.

Ключові слова: королівські столові маєтки, Самбірська економія, громадські суди, зборові суди, замкова влада, судочинство.

Problem statement. The judicial system in the king board manors of Rzecz Pospolita was rather complicated and cumbersome. This is because of the absence of the unified legal system in Rzeczpospolita, in general for all groups of people. The class, confessional, ethnic gradation of the society, the ambiguity of public and private law, the absence of a bureaucratic component at the lower administrative level prompted the variety of legal practices. The well-established rules and procedures, which were generally accepted throughout Rzecz Pospolita and understood in different parts of it, were combined with the local specific traditions that couldn't be found outside a specific region. The king board manors can serve as the typical model of the organization of the jurisdiction, which easily combined the abovementioned trends. Sandomierz (Sandomyr) economy, Sambir economy, Malbork economy were within the Polish land boundaries. On the territory of the modern Ukrainian lands one of them was located, that is Sambir economy.

The analysis of sources and recent researches. The management of the king board manors and the legal aspect of this organization were in the limelight for the Ukrainian and 
Polish historians. Some information can be found in V. Inkin's and Yu. Hoshko's work. Both researchers studied the specifics of Vlach law and its functioning in the areas of Sambir's economy. Both wrote a lot about the activities of the government public bodies, collegial and 'kraynytskyi' courts. In particular, they found the organizational forms and the procedure of their activities, the legislation they served; made a comparison with the similar legal practices of Ancient Rus' and the (Hoshko, 1999; Hoshko, 1976; Inkin, 1977; Inkin, 1986; Inkin, 1978; Inkin, 1975; Inkin, 1990; Inkin, 1996; Inkin, 1984). The high-level legal proceedings can be found in the works of E. Stanchak, who investigated the activities of the Royal Treasury Commission (Stańczak, 1973). In general, the mentioned topic is present in the scientific discourse, but needs further study.

The publication's purpose - the reconstruction of the judicial system in king board manors of Rus province in the XVIth - XVIIIth centuries

Statement of the basic material. The lower link of justice was formed at the level of rural communities. The eligibility of each member was equal and was restricted only to personally dependent subcommittees, comorbidities, minors, suspects and accused of a crime. In each case arising in the legal field, the community and its individual members serve as witnesses, experts, judges, defenders, intermediaries, etc. In the acts they were under the different names: «the entire mshanets' community», «trustworthy people», «unsuspected neighbors», «good people», «jury box», «mohorychnyky», etc (Inkin, 1996, p. 20). The fields of activity together with the organizational forms of the community-based legal proceedings activity and their government officials were diverse. In particular, the community was an indispensable participant as the third-party witness of purchase and sale agreements, pledges, making wills, the definition of boundaries, and so on. At the same time, the community could act not only as the passive witness, but also interfere in the property cases actively. For instance, the community has banned family property distribution in the XVIIIth century in Strilbychi village (SLLNU-SMHPDRB, c. 555/III, p. 100v). The community also took part in the special criminal cases investigations, especially, during the theft of cattle and any property, murders within its territory. In such cases, the community resorted to the socalled «persecution trail» that has been known since the creation of the «Ruska Pravda» (Rus' Law or Rus' Justice) (Inkin, 1986). The procedure was the following: when a theft or a murder happened, the community, on its own initiative or at the request of the injured party, was on the trail of the culprit to the community's frontier, if the culprit was not found on the territory of the community, then the criminal was passed to the neighbor community. As a result of the long-standing practice, there were numerous nuances, for example, the time of the trail persecution, how and to whom to pass the trail, who was involved in the trailing, on what kind of trail it was worth keeping the track or not etc. The «shaking of the house down» (searching for the offender within the community) and the «ruhovi courts» (had the character of a «total purge oath» and it was necessary to certify that the offender was absent) were also the main components of the customary public practice in the XVIth XVIIIth centuries (Vinnychenko, 2008, p. 514-515). The community could judge the suspect of committing the crime on their own and determine the degree of the guilt. If the community considered unanimously that the accused really deserves punishment and they handed down the relevant verdict («Konwinkacja», «konwinkować»), then it was an indisputable proof. Thus, the suspected man in the arson from Berezhnytsya village wasn't given the sentence, because of the local and neighbor communities defense. The man paid the fine, 10 hryvnias (SLLNU-SMHPDRB, c. 548/III, pp. 152v-153v). The composite courts (one of the public 
courts' type) had an interesting practice: the court was assigned to resolve the murder cases amicably for both sides of the trial and prevent the vendetta (blood revenge). The community was playing the dominant role during all stages of legal proceedings in this court, for instance, the community representatives were keeping an eye on following some rituals: along with the murderer the representatives were coming on by the victim's relatives, asking for the reconciliation. What's more, the community representatives were responsible for the murderer's life, hence, they protected him from the vendetta (blood revenge) and took part in making the composition agreement between both parties (Inkin, 1990, p. 72-85).

What was the main role of the public officials? The public officials along with the rest could participate in the abovementioned legal proceedings as the ordinary members of the community. However, in most cases, the duke-governs, the elders, the 'tyvuns', the atamans served as the initiators and the coordinators of the civil courts activities. The king board manors administration considered their participation in the legal proceedings to be of the highest legitimacy and legality. Apart from the participation in the community's legal activities, the government officials had a range of legal responsibilities. The duke-governs existed in Vlach law villages, had the right to summon their own courts, which dealt with the property cases of the community members and some trivial crimes («small affairs»): fights, quarrels, etc. They made the appropriate decisions like giving verdicts and imposed penalties, usually in the form of the fines - «guilty» (SLLNU-SMHPDRB, c. 514/III, pp. 1-276; d. 515/III, pp. 1-141). In German law (Magdeburger Recht; also called Magdeburg Law ) villages the legal proceedings were served by the ordinary ruling "viyty», but unlike the dukes they didn't conduct the trials on their own, the jury box and the community were taking part in the court trials, as a result, the essence of their existence was the leading role of the civil court (CSHAUL, f. 142, d. 1, c. 1, pp. 7, 10, 12-17, 29, 40, 47, 89, 91, 208, 241, 375, 378, 385).

The next link in the court system of king board manors after the public courts were the 'kraynyky' courts in the countries, key holders and collegial courts. These institutions served as the appellate courts on the decision of the civil courts. The legal proceeding was the following: the dukes, the ruling 'viyty' with the jury box were summoned from several neighbor villages, who were making the board of collegiates, such meetings were headed by the 'kraynyk' or the key holder in order to look into the case one more time (SLLNUSMHPDRB, c. 520/III., pp. 14-15). The collegiate court cases didn't differ much from the civil court cases if to compare. The collegiate courts could only look into the «small affairs», like beatenings, mutilatings, thefts, the «big affairs», like robberies, arson were removed from the jurisdiction of the court. However, the 'kraynyky' and the key holders didn't restrict themselves only to fines, like the civil courts, but also resorted to corporal punishment, which was widely practiced in the XVIIIth century (SLLNU-SMHPDRB, c. 538/III, pp. 34, 56; c. 525/III, pp. 8-8v). One more peculiar feature of the collegiate courts was the fact that they were the first institutions considering the land border disputes. The castle authority was the initiator, as a rule, and the collegiate courts were the castle authority representatives in turn (SLLNU-SMHPDRB, c. 520/III, pp. 364v-365v.). Quite often the administration gave them the forensics proxy in order to study the case on the spot, that is the functions of the judicial officer ('voznyi') with the subsequent consideration of the case in the castle and the adoption of a corresponding decree (BP SLLNU-SMHPDRB, c. 517/III, p. 857; c. 520/III, p. $463 \mathrm{v}, 467,519 \mathrm{v}-520,547 \mathrm{v}-548)$. In general, the 'kraynyky' and the officials were obliged to keep track of the order within the limits of their administrative-territorial unit The public officials were reporting to them about all cases of delinquencies and they were reporting 
accordingly in front of the castle authorities and at the meetings. By carrying out such police oversight functions, these officials could detain the criminals and keep them in custody until they were transferred to the castle (Inkin, 1975, p. 308).

Collegiate courts were the attribute of governance in the villages of Vlach Law. However, there were also the community keys where the villages of the Magdeburg Law (German law) and former villages of the Rus' law were grouped predominantly. They lasted until the XVIIth century, the so-called assemblage was mentioned and the communities of some keys were paying in the first half of the XVIIIth century (SLLNU-SMHPDRB, c. 566/III, p. 21). According to V. Inkin, the meeting of the countries took place initially, near Old Sambor and St. Savior (St. Spas) Monastery, and since the beginning of the XVIIth century - in the castle in New Sambir (Inkin, 1975, p. 305). Hvozsdetska and Pidbuzka countries were the exception, their meetings were held in Stara Sil and Banya Kotovska. In the XVIIIth century all countries, without exception, gathered for the meeting in New Sambir (SLLNUSMHPDRB, c. 538/III, pp. 23-79). The frequency of gathering the meetings was already established in the XVIth century, there were spring and autumn meetings. In the 60's of the XVIIIth century, all the countries without the exception gathered once a year in turns for their meetings, designated for universal administrator day, for example, in 1765 the meeting was held form the 3rd till 12th July, in 1768 - in $14-24$ of June (SLLNU-SMHPDRB, c. $538 / \mathrm{III}$, pp. 69,198 ; c. $551 / \mathrm{III}$, pp. 12 v, 39 , 51 v., 53 , 54 v; c. $550 / \mathrm{III}$, pp. 292 v, 378,383 , $388,529,537,602)$. The adult population of the country took part in the meetings. The turnout for the meetings was mandatory, a fine was imposed on the person, who didn't appear for the meeting. Apart from the communities, the other groups of the population, who lived in the country and weren't signed for any membership participated in the meetings. They were free people ('vilnyk'), village heads ('soltys-lannyk'), kochmars, millers, foresters, guards of the various services, dukes, 'kraynyk', Jewish-tenants (dealt with the community relationship matters), priests and the others. (Inkin, 1975, p. 307-308). The Higher Economy Administration was also mentioned as a member of the meeting participants. Thus, the Royal Commissars along with the sub-headman Jerzy Hoszowski and Lawrence Wodzicki, the administrator were present at the meeting in 1667 and in 1679 Stanisław Skarszewski, the administrator, took part in the meeting and in 1636 - Stanisław Trojan Gesłarowski performed as the deputy sub-headman (SLLNU-SMHPDRB, c. 514/III, p. 107v, 182; c. 536/III, pp. 232, 244; c. 548/III, pp. 575-575v). At Hvozdetsk and Pidbuzsk countries meeting, the castle administration was represented by Stara Sil and Kotovskyi 'pidzhupnyk' (the representatives of economy administration), and in the keys the castle administration was introduced by their subheadmen and the officers, for example, as in Oziminsk in 1599, Jan Záleský was mentioned as the «subheadman of Ozymynsk» along with Y. Mesnik (SLLNUSMHPDRB, c. 517/III, p. 372). As the representatives of the royal power, their duties were aimed at taking over the control of the meeting activities, but they didn't have the right to interfere in the work of the meetings. The whole power was concentrated in the hands of the board, which consisted of the dukes and 'kraynyk', actually, they were responsible for the organization of the decent meetings functioning (Inkin, 1975, p. 306).

The collegiate courts were looking into the appeals, which were submitted by the population of the country in order to make decisions and bylaws of the civil and 'kraynyk' courts. The government officials were presenting their report-books in which during the whole year they were putting down the information about the offenses and fines. The offenses and fines were reviewed by the judicial panels and some relevant notes were issued on the 
made decisions of approval or non-approval by the officials (Inkin, 1975, pp. 308, 318-319). On the basis of the community evidence, the court fines (of being «guilty») were verified. The royal representative received such kind of evidence annually, provided by the officials. The collegiate courts were not only taking control of the lower rank official's legal activities, by checking their records and correcting their court decrees, but also they were conducting their own judicial practice. The saved protocols of the collegiate courts that go back in times till $1659-1665$ and $1667-1670$ are full of numerous records about the offenses and the imposed sentences against them. (SLLNU-SMHPDRB, c. 514/III, pp. 1-276; c. 515/III, pp. 1-141). According to V. Inkin, the subject matter of the court cases that were investigated during the meetings was extremely diverse. For instance, the researcher has found more than 20 fines, mentioned in the Sambir Headman Inventories during 1558, 1568, 1585, some information was also found in the registers of the XVIIth century. The most common cases were dealing with 'golovshchyna', reluctance of giving the trace of the criminals, playing cards, 'potrava' (damage by cattle), beatings ('syni ta kryvavi razy'), 'zboyichyzna' or 'pozemshchyna' (that is the ransom, in a court, of the left thing or cattle by the thief) fines imposed for disobedience, for theft (pena furti), 'bykov' (for giving birth to a child out of the wedlock), divorce or 'rozvidnyi' (the dissolution of marriage), 'oborne' (the redemption of the lost cattle by the owner, driven to the castle), 'detske' (the ransom of the royal cattle captured in the woods), 'bludnyi' (the cattle left by the thief), 'virne' (the process of putting into ownership by a court on the basis of its decision or privilege), 'vidumershchuna' (the purchase of the real estate by the relatives of the childless dead person) (Inkin, 1975, p. 318-319). Most of the property cases, the civil court cases, as well as the criminal cases were under the jurisdiction of the collegial courts, the exceptions were only the most serious crimes related to the death penalty. Quite often the cases were sent from the castle to the collegiate courts, which were handed from the Vice-Administative court as the cases weren't related to the Vlach law. For instance, in 1626 A. Baranowski, the administrator handed over the mutual claims case for the collegiate court jurisdiction between Sambir bourgeois and the Jewish, the former and current tenants of Sambir flea market area (Inkin, 1975, p. 318-319). At the Hvozdetska country meeting could have considered cases that were under the jurisdiction of Stara Sil prosecutor's court. (SLLNU-SMHPDRB, c. 544/III, pp. $45 \mathrm{v}-46,49,50,67 \mathrm{v})$. In the XVIII century the legal functions of the meeting were minimised, and 'kraynyk' along with the castle court took over the main role, in the 1760's the boards of court meetings were no longer summoned and the cases weren't considered by them. (SLLNU-SMHPDRB, c. 538/III, pp. 24-69).

The 'pidzhupnytskyi' (prosecutor) courts, the vice-administrator courts, the administrative courts were the next link in the economy of the judiciary after the civil courts and the administrative courts. There was a separate litigation ('viytivsko-lavnychyi') court in Sambir and Staryi Sambir and in Stara Sil.

The existence of the 'pidzhupnytskyi' courts is closely connected with the pidzhupnyk's activities. One question that remains unresolved and should be elucidated is the power equality in legal spheres among Stara Sil 'pidzhupnytskyi' court, Kotovskyi‘pidzhupnytskyi' court and Drohobych 'pidzhupnytskyi' court. There is written evidence, the record case books that remained unchanged and preserved in Sambir economy archives about the legal proceedings of Stara Sil 'pidzhupnytskyi' court, covering the period of time since the 1605 till 1805 (SLLNU-SMHPDRB, cc. 551/III, 557/III, 544/III, 553/III, 570/III, 554/III, 545/III, 556/III, $543 /$ III, 561/III). The court was working continuously till the Sambir economy elimination 
and even for a short period of time during the Austrian occupation. There is no written pieces of evidence, the record case books of Kotovskyi'pidzhupnytskyi' court and Drohobych 'pidzhupnytskyi' court as the result of their legal activities didn't remained till our times, hence, it is unknown whether the following courts existed at all. However, we could make an assumption that Kotovskyi 'pidzhupnytskyi' court existed, as the abovementioned court was performing the 'kraynyk' duties of the Pidbuzh country for a long time (at least until the middle of the XVIIIth century). The sphere of legal activities of Stara Sil 'pidzhupnytskyi' court and Kotovskyi 'pidzhupnytskyi' court had in their subordination the territory where the 'zhupa' was located. 'Zhupa' or the population, permanently residing on that territories (the working staff) and on the local Hvozdetsk outskirts (more than 20 villages) and Pidbuzk local outskirts (about 10 villages), whose communities were obliged to perform various duties in the 'zhupa', such as the firewood delivery, salt export, equipment repair and maintenance (SLLNU-SMHPDRB, c. 552/III, pp. 45, 47v, 49, 67; CSHAUL, f. 856, d. 1, c. 106, pp. 46, 92-93.). In general, the 'pidzhupnytskyi' court and the castle court were dealing with the same legal cases. For example, the the 'pidzhupnytskyi' court considered the theft lawsuits, violence lawsuits, debts lawsuits. Stara Sil 'pidzhupnytskyi' court also investigated the saltwater fishing cases. In 1761 the case which dealt with the salt sales at lower prices by Stara Sil tradesmen, in 1749 the case about the provision of Drohobych by saltwater from the economic wells between Drohobych pidzhupnyk and Drohobych bourgeois representative was considered, in the same year, the complaints about the non-compliance with the conditions of lease by the Modrytsk kvotnyk were investigated (SLLNU-SMHPDRB, c. $556 /$ III, pp. $122-123 \mathrm{v}, 149-150$.).

The Vice-Administer's Court was the key body among the other judicial bodies of economy during the XVIIth - XVIIIth centuries. The court consisted of the vice-administrator and the scribe. Traditionally, the Vice-Administer's Court was summoned in the castle, but field visits were also practiced, in such cases the local officials joined the legal proceedings (SLLNU-SMHPDRB, c. 518/III, pp. 105, 256v). The frequency of the court convocation was $1-2$ days a week, if necessary, the court functioned continuously for several days in a row. The Vice-Administer's Court jurisdiction extended to the whole territory of the king board manors and the population living there, that's why, for some people the court was an appellate instance, for example, in the property cases, for others - it was the first institution, where the same property issues were solved. The people, who didn't dwell on the economy territory, but had some economic, financial, litigation cases with the local population and administration also turned to the Vice-Administer's Court for help. Those people could be, for example, the tradesmen and the merchants from the other cities, as Drohobych, Stryi, Przemyśl, Lviv, and the distant cities - Warsaw, Gdańsk, Toruń; the noblemen, and the clergy, whose estates were on the border with the economy, or those who visited the economy and due to different circumstances, were forced to resolve their affairs with the help of the court; the residents of Zabskid (SLLNU-SMHPDRB, c. 518/III, pp. 594-594v; c. 521/III, pp. 109v-110, 126-126v, 138, 185v).

The trial was conducted in the same way as in the other courts of economy, the both parties presented their information and the court made the final decision. If some circumstances remained unclear, then the additional investigation was carried out, for this purpose the government official was instructed to carry out the «inquisition» and to clarify the details in the local places. The kraynyk, the duke, the ruling vit, the voznyi could have acted as the government official. As a rule, the court looked into such kind of case after some period of 
time, usually after two or four weeks and took the appropriate decree (SLLNU-SMHPDRB, c. 542/III, pp. 239, 245, 247v). Sometimes the Vice-Administer's Court could have transferred the case to the specially created committees or to the other instances (SLLNU-SMHPDRB, c. 518/III, pp. 600-600v; c. 520/III, pp. 15-16, 30v-32, 40-41). For instance, in the XVIth - XVIIth centuries the murder cases which weren't connected with the robbery or the assassination, beating cases were considered by the amicable courts («compositio amicabilis, pojednanie, concordia»), the castle authority could have only determined the jury and ready signed decision-making agreement («zapowiedż o pokój») that were accepted for the case record books (Inkin, 1990, p. 72-74). The representative of the castle authority considered the land cases in order to meet the requirements of presence at the specific territory. As a result, the 'kraynyk', given proxy be the Vice-Administrator, looked into the land cases in the countries, while the castle authorities approved his decree (SLLNU-SMHPDRB, c. 518/ III, pp. 600-600v). The investigation of the serious crimes was carried out with the tortures and the people were sentenced to the death penalty. The serious crimes were transferred from the Vice-Administer Court to the civil viytivsko-lavnuchyi courts and to the similar judicial bodies in Chukva village and Nahuyevychi village (Inkin, 1984). There were numerous cases which the Vice-Administrator was unable to resolve on his own because of the limited possibilities, hence, such kind of cases were postponed until the arrivals of the economy administrator or the commissions. In addition to the abovementioned cases, the civil cases and the criminal cases were under the governor key holder jurisdiction. As the representative of the judiciary in economy, the Vice-Administrators were constantly involved in the commissions appointed by the Royal Treasury in order to resolve the complex cases. Some former Vice-Administrators gained much experience and knowledge over their working period and, as a result, they were used for the economy's interests protection in Supreme Courts. (CSHAUL, f. 43, d. 1, c. 193, pp. 692-693). In the judiciary system of the economy, the Vice-Administer Court was the appellate instance for the decisions of civil courts, kraynyk courts, collegiate courts, civil viytivsko-lavnychyh and state courts.

The decision-decrees carried out by the Vice-Administrators were supposed to be implementated by the lower government officials. The kraynyks, the key holders, the zhupnyks were responsible for the successful executions and the resolution compliances with the ruling court. There were special judicial officials: voznyi, instigators, in order to ensure the proper functioning of the castle courts. Their main duties were the preparation of the trial (the transfer of the lawsuit, the certification of all kinds of the physical damage and the material losses, and thereby giving them the status of evidence, carrying out the inquiries on the spot). Moreover, they supervised the implementation of the Vice-Administrative Court decrees in places, they also represented the castle authorities as one of the parties during the trials, rarely they were representing the economy's population - at court sessions.

When the administrator of the economy took part in the castle court meetings, such kind of trials felt into the Administrative Courts category, though they didn't differ from the ViceAdministrator's Court trials. The Administrator of the economy had the authority, which allowed him to resolve the cases that his governors didn't dare to. Hence, such cases, carried by the Administrative Court differed due to the covered issues. For instance, in 1616 Mykolay Danylovych dealt with the dispute between the community and the duke about the public field usage. In 1635 Yan Mykolay Danylovych considered the complaint of the village Storona community about the forcing of the illegal payments and the capturing of the public land by the duke (SLLNU-SMHPDRB, c. 518/II, pp. 92v-93; c. 548/III, pp. 546-546v). In 1716 the 
community of the village Strilky were complaining about the extortion of the zhovnir. The castle court decided to postpone the case untill the Administrator's arrival. What's more, the castle court had called for the summoning of the claims against the militants in two weeks terms, before Baron von Blumenthal arrived. (SLLNU-SMHPDRB, c. 542/III, pp. 99v-100). The cases about the violations of the land borders between villages and countries were also postponed, prior to the arrival of the Administrators (SLLNU-SMHPDRB, c. 519/III, pp. 198-198v). In relation to the Vice-Administrative Court and other judicial bodies of economy, the abovementioned court acted as an appellate instance (SLLNU-SMHPDRB, c. 518/III, p. 373). In the middle of the XVIIIth century, the castle court or the Vice-Administrator Court and the Administrator Court were named as the appellate court solely, in one of the rescripts of the Royal Treasury Commission. (SLLNUSMHPDRB, c. 565/III, pp. 112-112v). During the XVIIth and at the beginning of the XVIIIth century the courts were regarded as the first instance of the economy's population.

Conclusions. In the XVIth - XVIIIth centuries the judicial system in king board manors created a multilevel hierarchical model. Such kind of the multilevel hierarchical model was to a certain extent the reflection of the administrative apparatus since the government officials and the institutions were entrusted with the governing functions and were engaged in the legal proceedings. The civil courts, kraynyk courts, the collegiate courts formed the lower link of the judicial system in king board manors. They were the embodiment of the public administration relics, were based on the customary practice of the active involvement of the population in the legal field. The upper levels of the court system in king board manors consisted of the pidzhupnytskyi courts, the Vice-Administrative Courts and the Administrative Courts. They were organized by the administration as the castle courts (Sąd grodzki ) and the dominical courts in private estates.

Acknowledgments. The authors express their gratitude to the employees of the State Archive of Ivan Franko Lviv National University for the help in finding the historical documents.

Funding. The authors received no financial support for the research, authorship and publication of this article.

\section{BIBLIOGRAPHY}

Hoshko, Yu. H. (1976). Naselennia Ukrainskykh Karpat XV-XVIII st. [The population of the Ukrainian Carpathian Mountains in the XVth - XVIIIth centuries]. Kyiv: Naukova dumka, 205 p. [in Ukrainian]

Hoshko, Yu. H. (1999). Zvychaieve pravo naselennia Ukrainskykh Karpat ta Prykarpattia $X I V-X I X$ st. [Zvychayeve Pravo of the population of the Ukrainian Carpathian Mountains and Precarpathian region in the XIVth - XIXth centuries]. Lviv: Instytut narodoznavstva NAN Ukrainy, 336 p. [in Ukrainian]

Inkin, V. F. (1975). K voprosu o sotsialno-politycheskoi orhanizatsii galitskikh sjel na voloshskom prave (o sborakh-vechakh) [On the question of the socio-political organization of the Galician villages, based on the Volosh law (on meetings, viche]. Karpato-Dunaiskie zemli v srednie veka. Kyshynjev: «Shtyyntsa», 299-330. [in Russian]

Inkin, V. F. (1977). Volost (kraina) i veche (sbor) na Galitsyi v XVI - XVIII vv. [Volost and viche in Galicia in the XVIth - XVIIIth centuries]. Ezhehodnik po ahrarnoi istorii Vostochnoi Evropy. 1970 h. Riha: «Zinatne», 72-79. [in Russian]

Inkin, V. F. (1978). K voprosu o proiskhozhdenii y evoliutsii voloshskoho instytuta „kniazia” (kneza) $\mathrm{v}$ galitskoi derevne $\mathrm{VXV}-\mathrm{XVIII} v \mathrm{vv}$. [On the question of the origin and evolution of the Volosh Institute of «Duke» (knez) in the Galician village in the XV - XVIIIth centuries]. Slaviano-voloshskie sviazi. Sbornik statei. Kyshynjev: «Shtyyntsa», 116-141. [in Russian] 
Inkin, V. F. (1984). Silski sudy nimetskoho prava v Halychyni XVI - XVIII st. [Rural courts of German law in Galicia, in the XVIth - XVIIIth centuries]. Visnyk Lvivskoho derzhavnoho universytetu. Seriia istorychna, 20, 34-40. [in Ukrainian]

Inkin, V. F. (1986). Honenie sleda v galitskoi obshchinnoi praktike XV - XVIII vv. (material dlia obiasneniia 77-y stati Prostrannoi Pravdy) [Tracing trapping (honenie sleda) in the Galician community practice of the XVth - XVIIIth centuries (material for explanation of the 77th article of the Prostranna Pravda)]. Drevneishie hosudarstva na territorii SSSR. Materyaly i issledovaniia. 1985 hod. Moskva: Nauka, 131-140. [in Russian]

Inkin, V. F. (1990). Stati Russkoi Pravdy o mesti v svete obychnoi praktiki galitskikh obshchynnykh sudov po aktam XVI - XVIII vv. [The articles of the Rus' Pravda about revenge in the light of the usual practice of the Galician community courts on the acts of the XVIth - XVIIIth centuries]. Vestnyk Moskovskoho universiteta. Seria 8. Istoria, 1, 72-85. [in Russian]

Inkin, V. F. (1996). Instytut spivprysiazhnytstva ta hromadski silski sudy v halytskii zvychaievii praktytsi XVI - XVIII st. porivniano z Ruskoiu Pravdoiu [The Institute of Sincerity and public Rrural courts in the Galician conventional practice of the XVIth-XVIIIth centuries in comparison with the Rus' Pravda]. Ukraina moderna, 1, 18-41. [in Ukrainian]

Naukova biblioteka Lvivskoho natsionalnoho universytetu imeni Ivana Franka. Viddil rukopysnykh, starodrukovanykh ta ridkisnykh knyh im. F. P. Maksymenka [SLLNU-SMHPDRB - Scientific Library of the Ivan Franko National University of Lviv. The F.P. Maximenko Sector of Manuscript, Hand Press Druck and Rare Books].

Stańczak, Ed. (1973). Kamera saska za czasów Augusta III [The Saxon camera during the times of Augustus III]. Warszawa: «PWN», 221 s. [in Polish]

Tsentralnyi derzhavnyi istorychnyi arkhiv ukrainy, m. Lviv [CSHAUL - Central State Historical Archives of Ukraine, Lviv].

Vinnychenko, O. (2008). Do istorii silskoho sudochynstva: «Ruhove pravo» v halytskomu seli pochatku XVIII stolittia [To the history of village judicature: «Ruhove pravo» in Halychyna village at the beginning of of the XVIIIth century]. Drohobytskyi kraieznavchyi zbirnyk, XI-XII, 514-526. [in Ukrainian]

The article was received on February 12, 2019. Article recommended for publishing 10/06/2019. 